\title{
CORRESPONDENCE
}

Dear Sir,

\section{The Common Law in Lesotho}

I have just read Mr. S. M. Poulter's article, "The Common Law in Lesotho" in volume 13 of the J.A.L. ${ }^{1}$ It seems to me that both Mr. Poulter's method of analysis and his conclusions can be questioned on several grounds. The relevant part of the statutory text concerned (Proclamation 2 B of 1884 ) is short and is worth setting out again here by way of introduction to these comments:-

"In all suits, actions or proceedings, civil or criminal, the law to be administered shall, as nearly as the circumstances of the country permit, be the same as the law for the time being in force in the Colony of the Cape of Good Hope . . ."

As Mr. Poulter points out, legislation enacted by the Cape Parliament after 29th September, 1884, was expressly excluded by a later proviso in the same section.

One accustomed to modern legislation is struck by the open texture of the statute and by the enormous latitude for the working of judicial discretion which it seems to offer. If, after the rule in Heydon's case, one seeks the "mischief" at which the statute is aimed, it would appear to be nothing more or less than the absence of an adequate general framework for dealing with those future disputes and public delicts which fall outside the ambit of the customary law (another proviso makes clear that the customary law may be applied in cases between Africans). It is thus constitutional in character. The Proclamation provides a fundamental norm from which most of the norms of private law, in areas not otherwise regulated by statute, depend. Indeed it appears to be one of the more durable parts of the constitution of Lesotho, having survived even the suspension of the Independence Constitution in February of this year. ${ }^{2}$ As such, it ought to be interpreted in the manner of a constitution and not as one might interpret, say, a tax statute. Obviously the words cannot be disregarded but one can at least as legitimately seek after the flexibility in the language as attempt to fix a rigid and restrictive interpretation in accordance with canons of construction developed in dealing with other sorts of enactments. It is submitted, with great respect, that $\mathrm{Mr}$. Poulter has, in applying too rigid and literal an interpretative technique, created a problem which was not there before and which he is then obliged to deal with by a call for immediate repeal of the offending text.

It is obviously difficult to fault his analysis of the phrase "law for the time being in force ....". The authorities reviewed in his article are, to my mind, wholly persuasive and, in retrospect, it is

1 At [1969] J.A.L. 127.

See Lesotho Order, 1970, s. 3, promulgated by the Council of Ministers on Ioth February, 1970. 
surprising that the statute has been so readily assumed by others to refer to the Cape law at a fixed point in time rather than to the living, changing common law of the Cape. But perhaps this misinterpretation by the courts and other writers is partly explained by the tenor of the statute taken as a whole; by a broader conception of the "circumstances of the country" than Mr. Poulter is prepared to admit; by an unspoken sense of the constitutional import of the text.

Certainly one might wish that the troublesome phrase has been confronted and disposed of openly but it would not seem that much harm or even erroneous legal conclusions in decided cases are likely to have resulted from the oversight. A cursory examination of the reported decisions is enough to persuade one that the courts have followed not just Cape but South African decisions since 1884 quite as closely as one would expect them to have done if consciously acting on the interpretation suggested by Mr. Poulter.

But suppose there is occasion to depart from the South-African rules not because circumstances such as those mentioned by $\mathrm{Mr}$. Poulter do not "permit" the application of Cape law but because, on balance, it seems to the court that the preferable rule is not the South African rule. Can it do so? Leaving momentarily to one side the effect of the doctrine of stare decisis, it seems to me that a case can be made in support of the courts' freedom to do so which is at least as persuasive as Mr. Poulter's proposition that the courts of Lesotho are bound, by the 1884 Proclamation, to apply the common law of the Republic of South Africa.

Even on the most conservative and literal approach to the problem the question what is the law of the Cape Colony (in the sense of the Proclamation) is critical since that Colony ceased to exist as a separate, internally autonomous legal system upon its incorporation into the Union of South Africa in 1909. Whatever may have been the position prior to the South Africa Act, I909, I suggest that the law of the Cape Colony, simply and literally, can only be the law in force in that Colony during the period of its existence and, accordingly, that if the General Law Proclamation did not provide a cut-off date in 1884 , external events in effect imposed a cut-off in 1909. Can this view be reconciled with the language of the Proclamation? I see no reason why the disappearance of the referenced legal system cannot be considered a "circumstance of the country" affecting the extent to which the law developed in that system can be applied in Lesotho. There is no logical necessity that the word "circumstances" be limited to the internal circumstances of Lesotho. Even if comparable language has been interpreted more narrowly elsewhere, the absence of any limitation in time in the 1884 Proclamation certainly distinguishes it from general law statutes elsewhere and provides an ample justification for treating the Lesotho Proclamation as sui generis (if such is the effect of the interpretation which I suggest).

Mr. Poulter has suggested that we must apply the concept of succession to ascertain some contemporary living legal system to

${ }^{1}$ [1969] J.A.L. 133-136. 
which the Proclamation may now be deemed to refer. He does not tell us why this is so. It is a view which can be justified by giving primacy to the phrase "for the time being in force" at the expense of the other words of the statute, assuming thus that the legislative intention was such that one must be able to identify either the referenced legal system or its surrogate indefinitely into the future. Cape law is in effect, forbidden to cease to exist as a living legal system by the 1884 Proclamation.

Viewing the 1884 Proclamation as "constitutional" legislation, one can even more easily acknowledge that circumstances affecting the whole of the "country" (e.g., its political relationship to South Africa and to Britain) and of the state to whose legal system reference is made (e.g. its internal legal autonomy) may change to such an extent that any suggestion that there is a relevant connection between the legislative intention underlying the 1884 Proclamation and any existing legal system outside Lesotho becomes extremely difficult to justify. In 1884 , the common law of Lesotho was established with reference to the Cape common law. Without seeking to attribute improbable motives to the imperial legislator, it is clear that the Cape system was at that time the most humane and the least racial legal and political system in white-ruled Southern Africa. One might, at that time, have reasonably expected it to remain so and to become more liberal with the passing of time. The war between Britain and the Boer republics was yet ahead. Even after that war it was still possible to think of continued protection of the non-white franchise in the Cape and to contemplate the incorporation of the High Commission Territories into the Union. ${ }^{1}$ The rigorous apartheid of later years was, from the legal standpoint, non-existent. The formation of the Union with its consequent subordination of the Cape legal system to one in which the rule of any other South African jurisdiction or an altogether different rule might be imposed was not envisaged in 1884. In this perspective I would suggest that the relevant "circumstances of the country" are those which are reflected in the history of period between 1909 and 1966 when the prospects of incorporation of Lesotho into the Union were slowly and inevitably abandoned in the face of changing conditions in South Africa. $^{2}$

We cannot, and need not, review the actual legal history of Lesotho over the past 86 years. We need not even fix the point at which that system was cut loose from its mooring at the Cape and left to navigate alone-by dead reckoning, to pursue the metaphorwith occasional guidance from the Cape's successor systems. It is enough to conclude that this position has been reached without doing violence to the words of the 1884 Proclamation. This seems to me to be the correct position and to be the only position that is consistent both with the 1884 Proclamation and with the fact and necessity of the operation of an independent national legal system in Lesotho whose premises, as illustrated by the examples given by

1 See Schedule to the South Africa Act, 1909.

2 See History of discussions with the Union of South Africa, 1909-1939, Cmd. 8707. 
Mr. Poulter, are radically different from those of the Cape Colony's successor systems across the border.

This said, there is probably little point in disputing the name that one is to apply to the European-based part of Lesotho's common law. Obviously I would not agree that one should call it "South African" law. To persist in calling it "Roman-Dutch" law may be both inaccurate and perverse, as Mr. Poulter suggests, yet it is a neutral term and that is an important quality in Southern Africa. Moreover, from the standpoint of one who has taughtas a colleague of Mr. Poulter-within that system, it seems to me that adherence to the earlier name has another advantage. The Roman-Dutch system has been marvellously eclectic. Having roots in both civil and common law, it offers to the student, the lawyer and the judge the widest possible range of source materials. I encouraged my students to consider modern European as well as South African, English and early Dutch solutions to legal problems. The notion that the system is "Roman-Dutch" and thus not tightly bound to any contemporary foreign system can help to preserve this approach which opens important vistas for the creative solution of legal problems. To retain the term "Roman-Dutch" as a convenient way of designating a group of legal systems of common origin seems to me to make a great deal of sense and, in the taxonomy of legal systems, to serve a useful purpose, even if one does insist that the common law of the Republic of South Africa be called "South African".

Turning now briefly to the operation of judicial precedent, it will by now be apparent that I take the view that, at some point, possibly in 1909 but certainly not later than 1966 , the common law of Lesotho ceased to be merely an extension of the Cape common law and it will therefore be equally apparent that I also would conclude that subsequent to that point (or period) in time, external judicial decisions (i.e. decisions external to the hierarchy of courts competent to issue decisions in litigation commenced in Lesotho) no longer constituted binding precedents in Lesotho. This point is plainly linked to that first discussed above and need not be laboured here.

It must, however, be noted that Mr. Poulter's views in these matters have received recent support from a surprising source. Mr. Poulter has been kind enough to make available to me the text of section 7 of the Court of Appeal and High Court Order, No. 17 of 1970 , promulgated by the Council of Ministers (which has assumed full legislative powers since the suspension of the Independence Constitution in February of this year). It reads as follows:-

"(I) Notwithstanding anything to the contrary in any other law contained there shall be no appeal-

(a) from any judgment or order of the Court of Appeal given on appeal from any court in Lesotho; or

(b) from any judgment or order of the Court of Appeal given otherwise than on appeal.

(2) Notwithstanding any thing to the contrary in any other law contained no court and no person in Lesotho shall be bound by any 
judgment, order, ruling or opinion given by any tribunal, court, person or authority outside Lesotho after the date of commencement of this Order [8th May]. So however, that the provisions of this subsection shall not apply to any judgment, order, ruling or opinion given by the Judicial Committee of the Privy Council in connection with an appeal against a judgment given or made before 3oth January, 1970" [italics added].

Assuming that this provision has a purpose other than the abolition of appeals to the Judicial Committee (the generality of subsection (2) virtually compels such an assumption), it is extraordinarily difficult to imagine what judgments, orders and the like the legislator intended to exclude if not those which might be said to constitute judicial precedents in Lesotho. Certainly no others come readily to mind. It is however an extraordinarily poor piece of draftsmanship and it may simply have represented an effort to be absolutely sure that the Judicial Committee was eliminated from the Lesotho judicial system. It seems unlikely that the legislator was concerned with common law matters in the absence of any reference to the $\mathrm{r} 884$ Proclamation and rather that it was concerned with the application of specific judgments to the parties to the litigation in which the judgment was given. (One wonders what treatment a foreign divorce would now receive in Lesotho.)

In closing, I should like to express my appreciation both of the enormous effort and skill that $\mathrm{Mr}$. Poulter has brought to bear upon the much neglected legal problems of a small country and for his having given me the opportunity to read and criticize an earlier draft of his article. It was my pleasure to work closely with Mr. Poulter at the University of Botswana, Lesotho and Swaziland in 1967-68 and I only regret that my present circumstances do not permit a full and scholarly analysis of the propositions contained in his article.

Yours faithfully,

James E. Beardsley 